\title{
Pendidikan Reproduksi (Seks) Pada Remaja; \\ Perspektif Pendidikan Islam
}

\author{
Nuryadin \\ IAIN Palangka Raya \\ yadinnur5@gmail.com
}

\begin{abstract}
As a belief system that emphasizes intregral living world and the hereafter, Islam also has the attention to the problem of reproductive (sex education). Sex education in Islam is not only intended for individuals who have already reached puberty but is also aimed at children from an early age. One of the important phases of age in human life is adolescence (puberty). Sex education to adolescents have urgency as education and anticipation of deviant behavior inflicted on the puberty. Islam underlines sex education as an integral part of education monoteism, worship and morality. This paper presents an overview of reproductive education in adolescents according to the perspective of Islamic education.
\end{abstract}

Keywords: adolescents, sex education, Islamic education

\section{A. Pendahuluan}

Berbicara tentang seks tidak terlepas dari pembicaraan mengenai manusia itu sendiri. Manusia dilahirkan dengan potensi dan naluri seks terhadap lawan jenisnya, terlepas dari berbagai penyimpangan seks yang terjadi. Seks pada dasarnya merupakan kebutuhan alami atau naluriah makhluk hidup guna melangsungkan hidup dan melestarikan generasinya, seperti dijumpai pada manusia maupun makhluk hidupan lainnya. Jika seks dianggap tabu, terlarang dan jorok untuk dibicarakan atau dikaji, seolah-olah hal demikian tidak memberikan petunjuk atau pendidikan bagaimana memahami dan mengelola seks dalam lingkup kebermanfaatan dan makna yang positif. Berbagai penyimpangan dan kejahatan seksual yang marak dan melibatkan generasi muda, baik sebagai pelaku maupun sebagai korban, membuat kita prihatin. Sehingga dibutuhkan formula guna mencegah dan mengatasi problematika demikian.

Pendidikan seks pada remaja merupakan edukasi yang efektif guna memberikan wawasan, bimbingan, dan pencegahan bagi remaja dalam menghadapi persoalan seksual yang terjadi pada usianya serta bagaimana mengelola gejolak emosional yang terjadi. Di sinilah urgennya pendidikan yang bermuatan moralitas diinternalisasikan sejak dini sesuai perkembangan individu. Pendidikan yang berwawasan moralitas ini 
juga terkandung dalam pendidikan seks dengan pendekatan pendidikan Islam. Islam sendiri menekankan bahwa masalah reproduksi (seks) perlu dikelola sesuai tuntunan ilahi, misalnya melalui media pernikahan, dengan jalan berpuasa, menahan pandangan, dan sebagainya. Bila dibandingkan negara-negara lain seperti Jerman dan Belanda, implementasi pendidikan seks di Indonesia ${ }^{1}$ belum bersifat komprehensif. Pendidikan seks dalam bisa dikatakan belum banyak diimplementasikan dalam lingkup pembelajaran formal di lembaga-lembaga pendidikan. Pada realitasnya pendidikan seks lebih diintegrasikan (penyisipan) dalam pelajaran dan program tertentu daripada dalam bentuk pelajaran atau mata pelajaran khusus. Barangkali yang menjadi kendala dalam mewujudkan gagasan pendidikan seks dalam bentuk pelajaran khusus berkaitan dengan faktor psikologis, kebijakan pendidikan, dan kesiapan SDM itu sendiri. Nah, tulisan ini berupaya menyajikan konsep dan gagasan pendidikan seks pada remaja menurut perspektif pendidikan Islam.

\section{B. Kajian Pustaka}

Manusia adalah makhluk yang memiliki berbagai kompleksitas dan keunikan. Kompleksitas dan keunikan manusia merupakan potensi yang dapat berkembang ke arah positif maupun sebaliknya. Untuk mengaktualkan potensinya manusia membutuhkan bimbingan. Bimbingan ini pada awalnya diperoleh dari keluarga (orang tua) dan lingkungan sosial sekitarnya. Selanjutnya manusia itu sendiri dapat tumbuh dan berkembang secara mandiri seiring dengan pertumbuhan dan perkembangan dirinya menjadi dewasa. Manusia dalam mengarungi hidupnya senantiasa didasari oleh suatu pemikiran, pertimbangan dan dasar-dasar tertentu. Manusia tidak sekedar menjalani hidup tanpa pertimbangan. Terdapat pemikiran-pemikiran tertentu yang mendasari manusia dalam menginginkan dan meraih sesuatu.

\footnotetext{
${ }^{1}$ Pendidikan seks di Jerman telah menjadi bagian dari kurikulum sejak 1970 yang mencakup proses pertumbuhan, perubahan bentuk tubuh, emosi, proses biologis dan reproduksi, aktivitas sosial, kemitraan, homoseksualitas, kehamilan pranikah, komplikasi dari aborsi, bahaya kekerasan seksual, kekerasan seksual pada anak, penyakit menular yang diakibatkan hubungan seksual, posisi seks, dan alat kontrasepsi. Sementara di Belanda, pendidikan seks dimulai sejak akhir 1980 melalui paket Long Live Love. Melalui paket ini pemerintah membekali remaja dengan kemampuan membuat keputusan mengenai kesehatan dan seksualitas. Lihat Anshori LAL, Pendidikan Islam Transformatif (Jakarta: Referensi, 2012), hlm.94-95.
} 
Setidaknya ada tiga dasar motivasi dasar manusia dalam melakukan sesuatu , demikian menurut Witherington, yaitu lapar, proteksi diri dan seks. ${ }^{2}$ Nah, salah satu dasar atau motivasi manusia itu dalam berbuat adalah seks.

Secara bahasa seks berasal dari bahasa Inggris yaitu sex yang artinya jenis kelamin. Berkaitan dengan kata seks ini ada beberapa istilah yang mempunyai makna yang serupa yaitu seks, seksual dan seksualitas. Seks adalah proses reproduksi atau perbedaan karakter jenis kelamin, dan bisa juga berkaitan dengan segala hal yang berkenaan dengan kesenangan atau kepuasan organ digabung dengan rangsanganrangsangan organ-organ kemaluan atau terkait dengan percumbuan serta hubungan badan (koitus). ${ }^{3}$ Seksual adalah berkenaan dengan tingkah laku, perasaan atau emosiemosi yang digabungkan dengan rangsangan organ-organ kemaluan, daerah erogenous, atau digabung dengan proses reproduksi. Seksualitas adalah kapasitas untuk memiliki seks atau untuk mengusahakan hubungan persetubuhan atau karakter yang sedang tertarik pada sudut pandang seksual. ${ }^{4}$ Seks bersifat naluriah pada manusia. Seks juga merupakan kebutuhan dasar manusia. Jika manusia dikekang dan dikebiri hasrat seksnya maka akan muncul berbagai dampak negatif yang mengitarinya maupun dampak bagi lingkungan sekitarnya. Namun seks juga tidak bisa diberlakukan sebebas-bebasnya.

Sehingga dibutuhkan arahan, bimbingan, dan pengendalian terhadap perilaku seks manusia agar tidak berdampak negatif pada diri maupun lingkungan sosialnya. Di sinilah Islam sebagai agama yang menjunjung keseimbangan orientasi dunia dan akhirat berperan dalam membingkai dan mengarahkan naluri seks umat manusia melalui sumber ajarannya yang tertuang dalam al-Quran maupun sunnah nabi agar selaras dengan tuntunan ilahi. Islam tidah hadir sebagai pengekang apalagi mematikan nafsu seks. Islam memberikan panduan dan bimbingan bagaimana perilaku seksual memiliki manfaat dan bernilai positif (baca ibadah). Panduan dan bimbingan yang diberikan dimaknai sebagai pendidikan seks atau reproduksi (sex education). Pendidikan seks menurut perspektif Islam tentu memiliki perbedaan dengan pendidikan seks dalam perspektif Barat. Namun keduanya juga memiliki persamaan sehingga bisa saling melengkapi. Pertanyaannya kemudian adalah apakah pendidikan

\footnotetext{
${ }^{2}$ Saifuddin Mujtabah dan M. Yusuf Ridwan, Nikmatnya Seks Islami (Yogyakarta: Pustaka Marwa, 2010), hlm. 18.

${ }^{3}$ Marzuki Umar Sa'abah, Perilaku Seks Menyimpang dan Seksualitas Kontemporer Umat Islam (Yogyakarta: UII Press, 2001), hlm. 1.

${ }^{4}$ Ibid.
} 
seks itu? Apa tujuannya dan bagaimana hakikat pendidikan seks itu? Apakah pendidikan seks itu hanya sekedar teknik dalam berhubungan seksual semata atau ada hal lain yang melingkupinya? Bagaimana peran Islam dalam hal demikian? Inilah beberapa pertanyaan penting yang perlu dipecahkan agar tidak menimbulkan kesalahpahaman (misunderstanding) terhadap konsep pendidikan seks.

Ada beberapa definisi terkait pendidikan seks yang dikemukakan para pakar. Menurut Arif Rahman Hakim yang dikutip Anshori, pendidikan seks adalah perlakuan proses sadar dan sistematis di sekolah, keluarga dan masyarakat untuk menyampaikan proses perkelaminan menurut ilmu kesehatan, agama dan norma yang sudah ditetapkan masyarakat (moral). ${ }^{5}$ Utsman ath-Thawiil mendefinisikan pendidikan seksual sebagai pemberian pelajaran dan pengertian kepada anak laki-laki maupun perempuan sejak mereka mulai memasuki usia balig serta berterus terang kepadanya tentang masalah-masalah yang berhubungan seks, naluri dan perkawinan. ${ }^{6}$ Anshori LAL memaknai pendidikan seks menurut Islam sebagai pendidikan yang mengajarkan materi-materi tentang perkelaminan dalam kerangka ajaran agama. ${ }^{7}$ Definisi lain tentang pendidikan seks dikemukakan oleh pakar pendidikan Islam Abdullah Nashih Ulwan. Menurutnya pendidikan seks merupakan upaya pengajaran, penyadaran, dan penerangan tentang masalah-masalah seksual yang diberikan kepada anak, sejak ia mengerti masalah-masalah yang berkenaan dengan seks, naluri dan perkawinan. ${ }^{8}$

Beragam makna tentang pendidikan seks di atas memilik berbagai persamaan yakni pendidikan yang berhubungan dengan masalah seksualitas dan yang terkait dengannya yang diberikan oleh orang dewasa kepada generasi muda (usia dini, remaja dan dewasa) sesuai dengan kerangka ajaran agama (Islam), moral, dan kesehatan. Definisi di atas juga memberikan gambaran bahwa pendidikan seks itu bersifat komprehensif dan berkaitan dengan tauhid, ibadah, dan akhlak.

\footnotetext{
${ }^{5}$ Anshori LAL, Pendidikan Islam Transformatif..., hlm. 95.

${ }^{6}$ Utsman ath-Thawiil, Ajaran Islam tentang Fenomena Seksual terj. Saefuddin Zuhri, (Jakarta: PT. RajaGrafindo Persada, 1997), hlm. ix.

${ }^{7}$ Makna perkelaminan mencakup pengetahuan secara biologis (alat-alat reproduksi perempuan dan laki-laki), proses reproduksi (kehamilan dan kelahiran), dan pengetahuan dan pemahaman cara penularan PMS (penyakit menular seks) dan HIV/AIDS, perkembangan diri, alat kontrasepsi, mengenai perilaku seksual beresiko, orientasi seksual yang salah dan hak-hak manusia untuk keselamatan dan keputusan untuk melakukan hubungan seks dan sebagainya. Lihat Anshori LAL, Pendidikan Islam Transformatif..., hlm. 93-94.

${ }^{8}$ Abdullah Nashih 'Ulwan, Tarbiyatu ' $l$-Aulad $f i$ 'i-Islam, terj. Saifullah Kamalie dan Hery Noer Aly, (Semarang: Asy-Syifa', 1993), hlm. 572.
} 


\section{Metode Penelitian}

Penelitian ini menggunakan metode analisis deskriptif yakni suatu metode yang menganalisis data suatu objek kajian, kemudian mendeksripsikannya sesuai hasil analisis data tersebut

\section{Pembahasan}

Masa remaja adalah masa peralihan (transisi) dari masa anak-anak ke masa dewasa. Secara fisik remaja mungkin sudah menyerupai orang dewasa, namun secara psikis belumlah dewasa. Masa remaja berkisar antara usia 12 hingga 20 tahun. ${ }^{9}$ Masa remaja merupakan masa yang sangat rentan selama perkembangan hidup manusia, dimana hal tersebut merupakan saat yang menentukan bagi masa-masa selanjutnya. ${ }^{10}$ Masa remaja juga merupakan salah satu masa yang sangat penting dalam perjalanan hidup manusia. Jika masa ini dimanfaatkan dengan maksimal maka pengaruhnya sangat signifikan dalam kehidupan remaja selanjutnya, begitu pun sebaliknya.

Secara intelektual, remaja mulai mampu berpikir abstrak dan sebagian bahkan sudah mulai kritis. Secara emosional, remaja cenderung kurang stabil bahkan temperamental. Dalam pergaulan sosial, remaja lebih suka bergabung dengan temanteman seusianya. ${ }^{11}$ Ketiga aspek tersebut penting diperhatikan dalam kehidupan remaja oleh pendidik (orang tua, guru dan masyarakat). Jika aspek-aspek tersebut diabaikan tentu akan menimbulkan kepincangan dalam mendidik remaja. Kehidupan seorang remaja mencakup sisi intelektual, emosional dan sosial.nDalam Islam masa remaja berhubungan dengan usia balig yakni usia dimana seorang manusia (muslim) mulai dibebani dengan berbagai kewajiban dan konsekuensi dalam beragama. Pada perempuan usia balig biasanya berkisar pada usia antara 8-18 tahun, sedangkan pada laki-laki berkisar antara usia 12-20 tahun. Namun rata-rata usia permulaan balig lakilaki maupun perempuan berlangsung antara usia 12-15 tahun. ${ }^{12}$

\footnotetext{
${ }^{9}$ Heri Jauhari Muchtar, Fikih Pendidikan (Bangdung: Remaja Rosdakarya, 2008), hlm. 69. Masa remaja ditandai dengan pertumbuhan fisik yang sangat pesat seperti perubahan suara, tumbuhnya bulu pada tubuh bagian tertentu, tumbuhnya jakun pada pria, mulai membesarnya organ tubuh tertentu pada wanita serta berfungsinya organ-organ seksual baik pada laki-laki maupun perempuan. Masa ini juga ditandai dengan belum stabilnya emosi. Lihat ibid., hlm. 19. Bandingkan dengan uraian Mubin dan Ani Cahyadi yang membagi masa remaja menjadi tiga fase yaitu fase pra remaja (usia 12-14 tahun), fase remaja (usia 14-18 tahun), dan fase adolescence (usia 18-21 tahun). Lihat Mubin dan Ani Cahyadi, Psikologi Perkembangan, (Ciputat: Quantum Teaching, 2006), hlm. 106-110.

${ }^{10}$ Saifuddin Mujtabah dan M. Yusuf Ridwan, Nikmatnya Seks Islami..., hlm. 20.

${ }^{11}$ Lihat Mujiburrahman, Bercermin ke Barat: Pendidikan Islam Antara Ajaran dan Kenyataan (Banjarmasin: Jendela, 2013), hlm. 78-79.

${ }^{12}$ Utsman ath-Thawiil, Ajaran Islam..., hlm. 12.
} 
Ada berbagai faktor yang mempengaruhi seorang anak menjadi balig antara lain iklim, keturunan, makanan, kesehatan, dan keaktifan kelenjar dalam tubuh. ${ }^{13}$ Indikator balig pada remaja umumnya ditandai dengan aktivitas dan perubahan berikut; (1). Mimpi, yaitu keluarnya cairan sperma (mani) bagi laki-laki dan bukan mani bagi perempuan, sebagai hasil dari mimpi berhubungan seks ketika tidur. (2). Tumbuh rambut di sekitar alat kelamin. (3). Genap berusia 15 tahun. (4). Keluar haid bagi perempuan. ${ }^{14}$ Jika dikaitkan dengan naluri dan dorongan seksual, maka pada masa remaja dorongan tersebut sudah mulai tumbuh bahkan dapat dikatakan sangat bergejolak. Sedangkan pada masa kanak-kanak dorongan seksualitas, khususnya yang berhubungan dengan koitus (jima'), memang belum terasa. Tetapi setelah anak dalam usia remaja (balig), dimana organ-organ seksualitasnya mulai matang, maka kebutuhan koitus itu merupakan hubungan alami yaitu sebagai pemenuhan kebutuhan dasar seks, yang pada saat-saat itu memerlukan sambutan dari luar. ${ }^{15}$ Masa remaja adalah masa yang penuh kegelisahan dan gejolak. Fisiknya sudah mulai besar laksana orang dewasa, namun kenyataannya masih tergantung pada kedua orang tua. Naluri seksual mulai tumbuh dalam dirinya. Mulai tertarik dengan lawan jenis dan ada dorongan kuat agar dapat memuaskan naluri seksual tersebut. tetapi norma-norma sosial dan agama biasanya mengahalanginya untuk melakukan hal demikian sehingga muncullah kegelisah. ${ }^{16}$ Kegelisahan pada remaja mengantarkannya pada pencarian, percobaan dan mungkin tenggelam serta terjerumus pada berbagai aktivitas baik positif maupun negatif. Itulah mengapa masa remaja juga dikenal sebagai masa pubertas (puberty) yaitu periode dimana kematangan kerangka dan seksual terjadi dengan pesat terutama pada awal masa remaja. ${ }^{17}$

Setiap remaja akan mengalami masa pubertas dan berbagai gejolak yang melingkupinya. Pubertas adalah masa perkembangan fisik yang cepat ketika reproduksi seksual pertama kali terjadi atau pertama kali seorang laki-laki secara fisik

\footnotetext{
${ }^{13}$ Ibid., hlm. 13-14.

${ }^{14}$ Ibid., hlm. 15-17.

${ }^{15}$ Saifuddin Mujtabah dan M. Yusuf Ridwan, Nikmatnya Seks Islami..., hlm. 19. Bandingkan dengan pendapat Ahmad Azhar Basyir yang menyatakan bahwa kepribadian kelamin (seks) mulai tumbuh pada anak-anak setelah berusia 7 tahun (masa tamyiz). Pada masa ini anak-anak dapat membedakan banyak hal yang baik maupun buruk dan seterusnya, terutama membedakan antara jenis kelaminnya dengan jenis lain, laki-laki atau perempuan. Pada usia 10 tahun, kesadaran pribadinya sudah memasuki masa pancaroba. Lihat Ahmad Azhar Basyir, Ajaran Islam tentang Pendidikan Seks, Hidup Berumah Tangga, Pendidikan Anak (Bandung: Al-Ma'arif, 1996), hlm. 11-12 dan Desmita, Psikologi Perkembangan, (Bandung: Remaja Rosdarkarya, 2008), hlm. 222.

${ }^{16}$ Lihat Mujiburrahman, Bercermin ke Barat..., hlm. 78.

${ }^{17}$ Desmita, Psikologi Perkembangan, hlm. 192.
} 
mampu menghamili seorang perempuan dan seorang perempuan secara fisik sanggup mengandung dan melahirkan bayi. Pubertas berkaitan dengan perubahan fisik yang terjadi selama masa pra-remaja dan masa remaja. Sementara masa remaja (adolescence) adalah perubahan emosi dan perubahan sosial pada masa remaja. Masa remaja biasanya terjadi sekitar 2 tahun setelah masa pubertas yang menggambarkan dampak perubahan fisik dan pengalaman emosional mendalam. ${ }^{18}$ Pada fase remaja dorongan seksual mulai muncul dalam diri individu. Di sinilah sisi mental dan sosialnya mulai bergejolak dan remaja pada fase ini berupaya mencari dan menemukan jati dirinya. Kemudian remaja melakukan tindakan baik secara individu maupun dengan teman sebayanya guna mencari dan memantapkan siapa dirinya. Pada masa ini pula remaja mudah gamang dan goyah serta belum memiliki kestabilan mental. Sehingga pada fase ini, remaja membutuhkan pengawasan dan bimbingan edukatif.

Walaupun remaja mulai tumbuh ke arah manusia dewasa, pada hakikatnya remaja membutuhkan bimbingan dalam membantunya menjalani fase penting dan genting dalam kehidupannya. Remaja memerlukan lingkungan dan pendidikan yang mampu mengarahkan dan mendorongnya secara aktif baik dalam lingkup kehidupan privat maupun sosial yang seimbang. Remaja jika dilihat dari kebutuhan dan kecenderungannya memiliki tujuh kebutuhan. Kebutuhan tersebut merupakan keniscayaan bagi remaja pada masanya. Jika kebutuhannya tidak terpenuhi atau terhambat, maka remaja akan berontak dan bergejolak. Kebutuhan-kebutuhan tersebut meliputi kebutuhan kasih sayang., kebutuhan keikutsertaan dan diterima dalam kelompok, kebutuhan mandiri, kebutuhan untuk berprestasi, kebutuhan pengakuan dari orang lain, kebutuhan untukdihargai, kebutuhan untuk memperoleh fasilitas hidup. ${ }^{19}$

Salah satu dimensi pendidikan yang perlu diinternalisasikan pada masa remaja guna memberikan bekal dalam mengaruhi kehidupannya adalah pendidikan seks menurut perspektif Islam. Islam telah memberikan panduan bagaimana pendidikan seks pada remaja. Pendidikan seks pada remaja ditekankan pada pengetahuan dan bimbingan seputar hubungan perkelaminan yang meliputi wawasan dan edukasi

\footnotetext{
${ }^{18}$ Robert P. Masland dan David Estridge, Apa yang Ingin Diketahui Remaja tentang Seks terj. Mira T. Windy, (Jakarta: PT. Bumi Aksara, 2000), hlm. 1.

${ }^{19}$ Heri Jauhari Muchtar, Fikih Pendidikan..., hlm. 70.
} 
seputar naluri seks, sistem reproduksi, ${ }^{20}$ perkawinan, kewajiban agama, dan penyimpangan seksual. Pendidikan seks pada remaja bukan ditekankan pada teknis berhubungan seks. Islam lebih menekankan bahwa pendidikan seks harus diberikan sesuai dengan perkembangan usia dan jiwa seseorang.

Daya tarik seks pada manusia sebenarnya sama alamiahnya dengan yang terdapat pada spesies binatang lain, walaupun motivasinya berbeda-beda. Sehingga seks tidak bisa dianggap sebagai sesuatu yang jorok dan tercela sebab seks merupakan bagian dari sunatullah. ${ }^{21}$ Manusia sendiri membutuhkan seks karena hal tersebut merupakan bagian dari upaya melahirkan dan melestarikan keturunan. Berbicara tentang seks dalam Islam tidak bisa dilepaskan dari ajaran Islam itu sendiri, karena di situlah acuan umat dalam menggali, mengkaji dan mengembangkan tema seputar seksual. Tema seks dalam Islam juga tidak terlepas dari bahasan akidah, ibadah dan akhlak. Seks selalu berkaitan dengan ketiga hal tersebut. Islam hadir sebagai penyempurna kehidupan umat manusia, yang memiliki keseimbangan orientasi dunia dan akhirat. Seks sebagai naluri alami manusia mendapat tempat dalam ajaran Islam yang dibawa oleh nabi Muhammad saw. Islam mengatur bagaimana seks ditempatkan sebagai bagian dari proses regenerasi umat manusia, bagian kesenangan dan penyaluran hasrat seks secara benar dan bermanfaat. Jika ditelaah lebih lanjut banyak sumber ajaran Islam dalam al-Quran maupun hadis nabi yang berkaitan dengan kehidupan seksual manusia. Islam telah memberikan bimbingan pendidikan seks sejak manusia itu lahir yang ditandai dengan berbagai aktivitas edukatif seperti mengazankan bayi yang baru lahir, mendoakan dan meminta perlindungan Allah, mengaqiqahkan bayi, mengkhitankan anak laki-laki, ajaran menutup aurat, mengajarkan salat pada masa anak-anak, larangan melihat aurat, larangan melihat lawan jenis dengan hasrat dan lain sebagainya. ${ }^{22}$

Dalam al-Quran terdapat beberapa ayat yang berbicara tentang masalah seks dengan bahasa dan ungkapan metafor. Di antaranya dalam Q.S. Ali Imran [3]: 14.

Dijadikan terasa indah dalam pandangan manusia cinta terhadap apa yang diinginkan berupa perempuan-perempuan, anak-anak, harta benda yang

\footnotetext{
${ }^{20}$ Sistem reproduktif adalah sebuah kelompok yang berhubungan dengan organ-organ di dalam tubuh manusia yang memiliki dua fungsi utama yaitu menjalankan berbagai macam aktivitas seksual dan mengandung (hamil) yang menyebabkan kelahiran. Lihat ibid., hlm. 15.

${ }^{21}$ Faramarz bin Muhammad Rahbar, Selamatkan Putra-Putrimu dari Lingkungan Tidak Islami terj. Kamdani (Yogyakarta: Mitra Pustaka, 1999), hlm. 121.

${ }^{22}$ Lihat Ali Akbar, Seksualitas Ditinjau dari Hukum Islam (Jakarta: Ghalia Indonesia, 1983), hlm. 86-94.
} 
bertumpuk dalam bentuk emas dan perak, kuda pilihan, hewan ternak dan sawah ladang. Itulah kesenangan hidup di dunia dan di sisi Allahlah tempat kembali yang baik.

Selain ayat di atas, terdapat ayat-ayat lain yang berkaitan yaitu Q.S. an-Nisa [4]: 1, Q.S. al-A'raf [7]: 80-81, Q.S. Yusuf [12]: 23-30, Q.S. al-Isra [17]: 32, Q.S. alMu'minun [23]: 5-7, Q.S. an-Nur [24]: 30-31 dan 59-61, Q.S. ar-Rum [30]: 21, Q.S. al-Ahzab [33]: 59, Q.S. al-Hujurat [49]: 13, Q.S. aż-Żariyat [51]: 49, dan Q.S. anNajm [53]: 45-46. Dalam hadis pun dijumpai berbagai riwayat yang berbicara tentang pendidikan seks.

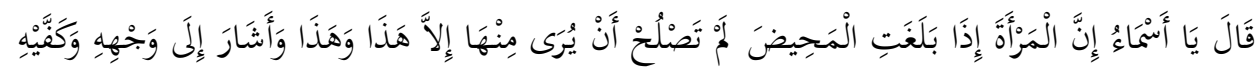

Terjemahnya:

"Wahai Asma: Sesungguhnya seorang wanita, apabila telah balig (mengalami haid), tidak layak tampak dari tubuhnya kecuali ini dan ini (seraya menunjuk muka dan telapak tangannya)." (HR Abu Daud).

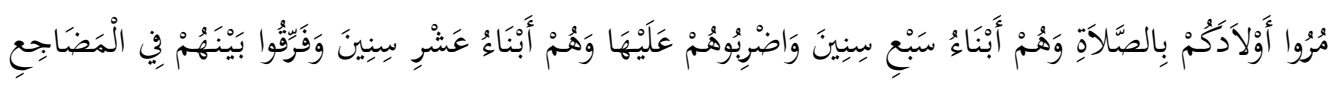

Terjemahnya:

"Perintahkan anak-anak kalian untuk melakukan shalat saat mereka berusia tujuh tahun, dan pukullah jika mereka telah berusia sepuluh tahun, serta pisahkan mereka di tempat tidur mereka." (HR. Abu Daud).

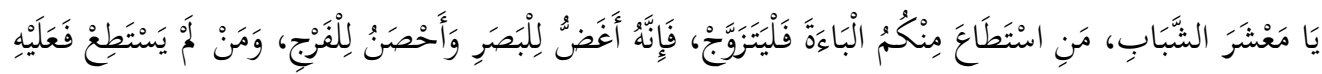

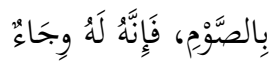

Terjemahnya:

"Wahai para pemuda, barangsiapa di antara kalian yang mampu menikah, maka menikahlah. Karena menikah lebih dapat menahan pandangan dan lebih memelihara kemaluan. Dan barangsiapa yang tidak mampu, maka hendaklah ia berpuasa; karena puasa dapat menekan syahwatnya (sebagai tameng)."

$$
\text { عن ابن عباس رضي الله عنه قال :قال رسول الله صلى الله عليه وسلم :إياكم والزنا فإن فيه أربع خصال }
$$

Terjemahnya:

"Dari Ibnu Abbas ra berkata Rasulullah saw bersabda: Jauhilah perbuatan zina, karena di dalamnya ada empat hal; menghilangkan cahaya wajah, 
memutuskan rizki, membuat murka Tuhan Yang Maha Pengasih, dan menyebakan pelakunya kekal di dalam neraka." (HR. Tabrani).

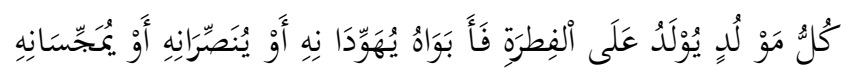

Terjemahnya:

"Setiap anak yang dilahirkan adalah suci, orang tuanyalah yang menjadikan ia Yahudi, Nasrani atau Majusi.” (HR. Abu Ya'la, Baihaki dan Tabrani).

Dalam Islam seks berkedudukan sebagai pembeda antara jenis laki-laki dan perempuan, yang selanjutnya berkaitan pula dengan hak dan kewajiban masingmasing. Seks juga sebagai sarana pengembangbiakan manusia dari generasi ke generasi. Selain sebagai pembeda jenis kelamin dan sarana pengembangbiakan umat manusia, seks juga sebagai pembinaan peradaban. ${ }^{23}$ Seksualitas dalam Islam selalu berhubungan dengan kehidupan berkeluarga. ${ }^{24}$ Keluarga merupakan insitusi penting dalam mengejawantahkan nilai-nilai Islam tentang pendidikan seks. Keluarga merupakan salah satu tujuan dalam kehidupan seks manusia (umat Islam). Keluarga dibentuk dan dibangun melalui sarana seks yang dibingkai dengan norma agama dan sosial.

Islam mengajarkan bahwa masalah seks bukanlah sesuatu yang buruk. Mempelajari masalah seks (pendidikan seks) dalam Islam juga tidak boleh sembarangan tanpa bimbingan dan arahan dari orang dewasa (pendidik). Ada tahapan dan prioritas tertentu yang ditekankan dalam pendidikan seks sesuai dengan perkembangan usia individu, termasuk remaja. Karenanya mempelajari pendidikan seks merupakan upaya dalam mengajarkan dan mendidik manusia agar memiliki etika dalam hubungan seksual dan implikasi yang terkait dengannya. Ada beberapa prinsip fundamental tentang pendidikan seks dalam Islam yaitu; (1). Seksualitas adalah sesuatu yang sehat dan alami dalam kehidupan. (2). Kenikmatan seksual adalah bagian dari rahmat Tuhan. (3). Seksualitas dalam Islam terkait dengan ibadah ritual seperti salat, puasa, haji. (4). Seksualitas terkait dengan kehidupan berkeluarga karena itu pre-marital seks dan extra-marital seks (zina) dilarang dalam Islam. (4). Orang tua

\footnotetext{
${ }^{23}$ Dalam al-Quran terdapat beberapa ayat yang berkaitan dengan kedudukan seks yaitu an-Najm (53): 45-46, an-Nisa (4): 1 dan al-Hujurat (49): 13. Lihat Muhamad Thalib, Bimbingan Kemesraan dan Seksualitas Islami (Yogyakarta: Pro-U Media, 2008), hlm. 306-310.

${ }^{24}$ Alimatul Qibtiyah, Paradigma Pendidikan Seksualitas Perspektif Islam: Teori dan Praktik (Yogyakarta: Kurnia Kalam Semesta, 2006), hlm. 70.
} 
dan pendidik seksualitas harus memberikan informasi yang benar dan dipercaya. (5). Seorang muslim tidak menunjukkan auratnya kecuali pada pasangan dan orang-orang tertentu. (6). Puasa adalah salah satu solusi untuk mengontrol hasrat seksual. (7). Hubungan dan kepuasan seksual harus dirasakan secara adil antara suami dan isteri. ${ }^{25}$

Prinsip-prinsip tersebut jika ditelaah lebih dalam menunjukkan bahwa Tuhan menganugerahkan hasrat seks pada manusia sebagai upaya dalam melestarikan generasi manusia yang dibingkai dengan nilai-nilai keislaman dalam konteks tauhid, ibadah dan akhlak. Prinsip-prinsip tersebut dengan sendirinya menjadi acuan bagaimana mengimplementasikan pendidikan seks itu dalam ranah teoritis dan praktis. Basis ontologis, epistemologis, dan aksiologisnya sendiri memiliki pijakan yang kokoh.

Pendidikan seks tidak hanya terkait dengan urusan seksual semata. Pendidikan seks memiliki arah maupun tujuan. Ada berbagai tujuan yang diberikan para ahli terkait pendidikan seks bagi remaja itu sendiri baik ditinjau dari sudut pandang Islam maupun perspektif lain (Barat). Tujuan pendidikan seks di antaranya, (1). Memberikan pengertian yang memadai mengenai perubahan fisik, mental dan proses kematangan emosional yang berkaitan dengan masalah seksual pada remaja. (2). Mengurangi ketakutan dan kecemasan sehubungan dengan perkembangan dan penyesuaian seksual (peran, tuntutan dan tanggung jawab). (3). Membentuk sikap dan memberikan pengertian terhadap seks dalam semua manifestasi yang bervariasi. (4). Memberikan pengertian bahwa hubungan antara manusia dapat membawa kepuasan pada kedua individu dan keheidupan keluarga. (5). Memberikan pengertian mengenai kebutuhan nilai moral yang esensial untuk memberikan dasar yang rasional dalam membuat keputusan berhubungan perilaku seksual. (6). Memberikan pengetahuan tentang kesalahan dan penyimpangan seksual agar individu dapat menjaga diri dan melawan eksploitasi yang dapat mengganggu kesehatan fisik di dalamnya. (7). Untuk mengurangi prostitusi, ketakutan terhadap seksual yang tidak rasional dan eksploitasi seks yang berlebihan. (8). Memberikan pengertian dan kondisi yang dapat membuat individu melakukan aktivitas seksual secara efektif dan kreatif dalam berbagai peran. $^{26}$

\footnotetext{
${ }^{25}$ Ibid., hlm. 72.

${ }^{26}$ Anshori LAL, Pendidikan Islam Transformatif..., hlm. 96.
} 
Pandangan mengenai tujuan pendidikan seks bagi remaja menurut Islam disampaikan Utsman ath-Thawiil adalah; (1). Memberikan informasi yang benar dan memadai kepada generasi muda muslim sesuai dengan kebutuhannya ketika memasuki usia balig. (2). Memberikan peringatan kepada anak-anak muslim tentang rencana busuk Yahudi beserta antek-anteknya. (3). Menjauhkan generasi muda muslim dari jurang kenistaan dan lembah kemesuman. (4). Mengatasi problematika seksual pada remaja melalui perspektif Islam yang jauh dari hal-hal yang dapat menimbulkan rangsangan seksual. (5). Menjauhkan generasi muda muslim dari teori serta kebohongan yang sengaja disebarkan oleh agen-agen Yahudi. (6). Menampilkan keuniversalan, kesempurnaan, relevansi dan keampuhan Islam dalam mengatasi problematika yang dihadapi umat manusia di manapun dan kapanpun. (7). Memperkokoh metode Islam dalam memelihara kemuliaan diri sehingga generasi muda muslim diharapkan mampu menjelma seperti akhlak para nabi dan seperti kesucian para malaikat dan seperti para pendahulu yang saleh dalam memelihara kesucian. (8). Agar pemuda-pemudi Islam dapat mengerti serta mampu membedakan yang dihalalkan dan yang diharamkan yang berkaitan dengan hubungan seksual. ${ }^{27}$

Dari perspketif lain tujuan pendidikan seks bagi remaja di sekolah di antaranya; (1). Membantu remaja mengetahui topik-topik biologis, seperti pertumbuhan, pubertas dan kehamilan. (2). Mencegah anak-anak dari tindakan yang mengeskpresikan penyimpangan. (3). Mengurangi kesalahan, keadaan yang memalukan dan menggelisahkan akibat tindakan seksual. (4). Mendorong menjalin persahabatan yang baik. (5). Mengembangkan persahabatan yang baik dan saling menghormati perbedaan antara sesama. (6). Mencegah anak-anak di bawah umur dari hal-hal yang memikat hati dalam persoalan hubungan seksual. (7). Mencegah kehamilan pada anak-anak gadis di bawah umur belasan tahun. (8). Mengurangi halhal yang mengindikasikan penularan penyakit lewat seksual. (9). Membantu peran pemuda sebagai laki-laki dan perempuan di masyarakat. ${ }^{28}$

Beragamnya tujuan pendidikan seks bagi remaja di atas memiliki orientasi yang hampir sama yaitu mengedukasi remaja seputar masalah seksual dan yang terkait serta mengantisipasi remaja dari perilaku penyimpangan seksual. Walaupun

\footnotetext{
${ }^{27}$ Utsman ath-Thawiil, Ajaran Islam..., hlm. xvi-xvii.

${ }^{28}$ Lihat J. Mark Halstead dan Michael Reiss, Sex Education Nilai dalam Pendidikan Seks Bagi Remaja; Dari Prinsip ke Praktek terj. Kuni Khairun Nisak, (Yogyakarta: Alenia Press, 2004), hlm. 274-303.
} 
demikian, terdapat pula beberapa perbedaan seperti tekanan pada nilai-nilai keislaman yang tidak terdapat dalam perspektif lain. Bisa dikatakan secara teoritis, Islam menekankan keseimbangan antara tauhid, ibadah, dan akhlak dalam memandang pendidikan seks.

Pendidikan seks dalam Islam adalah satu paket dengan pendidikan nilai lainnya. Pemisahan seks dari pesan-pesan Islam akan berdampak pada hilangnya sasaran yang hendak dicapai dalam pembinaan moral Islam. ${ }^{29}$ Dalam pendidikan seks, Islam mengutamakan pendidikan rohaniah, moral, etika sejak bayi dengan meletakkan dasar iman kepada Allah. Sementara pengetahuan tentang anatomi, fisiologi dan psikologi dapat ditambahkan sebagai pelengkap sesuai dengan jenjang pendidikan dan usia. Sebaliknya pendidikan seks yang dimulai dengan pengetahuan anatomi, fisiologi dan psikologi akan mudah merangsang daripada menahan nafsu seks. ${ }^{30}$ Oleh karena itu, pendidikan seks bagi remaja dalam Islam harus dibingkai dan diutamakan pada penanaman nilai-nilai keilahian, kemudian dilanjutkan dengan pengetahuan dan informasi seputar anatomi, fisiologi dan psikologi seksual manusia. Untuk membantu dalam implementasi dalam ranah praktis pendidikan seks bagi remaja memiliki kurikulum ataupun cakupan materi yang dapat digunakan sebagai referensi atau bahan kajian. Kurikulum pendidikan seks yang islami menurut Anshori LAL mencakup aspek-aspek berikut,

1. Pertumbuhan dan perkembangan seksual,

a. Masa tamyiz (masa pra pubertas) yaitu usia antara 7-10 tahun.

b. Masa muraqahah (masa peralihan atau pubertas), yaitu usia antara 10-14 tahun.

c. Masa baligh (masa adolesen) pada usia 14 tahun-16 tahun.

d. Masa pemuda, ditandai dengan perubahan fisik selama masa pubertas dan kebutuhan akan kehidupan keluarga.

2. Fisiologi dari sistem reproduksi.

3. Kehamilan dan kelahiran.

4. Penyakit-penyakit kelamin (HIV/AIDS).

5. Aspek mental, emosi dan sosial pada masa pubertas.

6. Etika sosial, moral dan religius pada masa pubertas yang meliputi,

a. Menanamkan rasa malu pada anak.

\footnotetext{
${ }^{29}$ Marzuki Umar Sa'abah, Perilaku Seks Menyimpang..., hlm. 244 dan 251. Lihat juga Ali Akbar, Seksualitas Ditinjau..., hlm. 17.

${ }^{30}$ Ali Akbar, Seksualitas Ditinjau..., hlm. 26.
} 
b. Menanamkan jiwa maskulinitas pada anak laki-laki dan jiwa feminimitas pada anak perempuan.

c. Memisahkan tempat tidur anak ketika berusia 7 tahun (dengan orang tua dan anak yang berlainan jenis).

d. Mendidik anak agar senantiasa menjaga kebersihan alat kelaminnya.

e. Mengenalkan anak tentang muhrimnya.

f. Mendidik anak agar senantiasa menahan pandangannya dari hal yang dapat mengarahkan pada dorongan seksual.

g. Mendidik anak agar tidak melakukan ikhtilat (bercampurbaurnya laki-laki dan perempuan non-mahram tanpa ada keperluan yang dibolehkan syara').

h. Mendidik anak agar tidak melakukan khalwat (berdua-duaan dengan nonmahram).

i. Mengajarkan anak etika berpakaian yang menutup aurat.

j. Mengenalkan ihtilam (mimpi basah) pada anak laki-laki dan haid pada anak perempuan serta kewajiban yang terkait dengannya.

k. Mendidik anak agar senantiasa isti'faf(menjaga kehormatan diri).

7. Mengajarkan cara menghindari pengaruh negatif dari teman. ${ }^{31}$

Tawaran kurikulum yang disampaikan Anshori di atas menunjukkan bahwa pendidikan seks tak hanya berhubungan dengan aspek fisiologi dan sistem reproduksi semata, tetapi mencakup aspek lain yang lebih luas dan memiliki kaitan erat. Pendidikan seks dengan demikian dapat diimplementasikan dalam lembaga pendidikan baik dalam cakupan materi (tematik) dan subjek pelajaran khusus maupun terintegrasi dengan pelajaran lain seperti pelajaran agama, ilmu pengetahuan alam, ilmu pengetahuan sosial dan pelajaran terkait. Tidak ada metode tertentu yang mutlak digunakan dalam pendidikan seks bagi remaja. Namun pada dasarnya remaja membutuhkan ruang berbagi, ekspresi dan apresiasi. Dari sini pendidik dapat berkaca bahwa dalam memanfaatkan metode maupun strategi pendidikan harus sesuai dengan jiwa dan karakter remaja. Berbagai pendekatan, strategi, metode, dan teknik pembelajaran dapat digunakan secara bervariasi sesuai dengan materi, kondisi remaja, dan aspek lainnya. Strategi dalam internalisasi pendidikan seks harus disesuaikan dengan tujuan, tingkat pemahaman, tingkat kedalaman materi, usia anak, tingkat

${ }^{31}$ Lihat Anshori LAL, Pendidikan Islam Transformatif..., hlm. 101-108. 
pengetahuan dan kedewasaan anak, dan media yang digunakan oleh pendidik serta dikaitkan pula dengan tradisi lokal yang positif, moral, dan ajaran agama. ${ }^{32}$

Jika melihat uraian di atas berkenaan maka dalam konteks pendidikan di Indonesia, pendidikan seks pada remaja bisa diberikan dengan cara mengintegrasikannya dengan mata pelajaran terkait maupun dengan pelajaran khusus yang bersifat berdiri sendiri. Keduanya merupakan upaya efektif dalam mengedukasi remaja dalam memahami dan menyadari persoalan seksual dan implikasinya dalam bingkai ajaran Islam. Pendidikan seks lebih lanjut berlaku untuk semua lapisan umur dengan penekanan yang berbeda. ${ }^{33}$ Pendidikan ini harus diberikan dan dipahami oleh setiap muslim dan diajarkan sejak manusia lahir dan orang yang pertama bertanggungjawab terhadap pendidikan ini adalah orang tua dalam rumah tangga. ${ }^{34}$

Dalam Islam, ada beberapa hal yang penting diperhatikan pada remaja berkaitan dengan pendidikan seks yaitu

1. Ajarkanlah masalah seksual sesuai dengan tahapan usia dan perkembangan kejiwaannya. Dasar-dasar hubungan seksual tidak boleh diajarkan kecuali jika mereka sudah berusia dewasa (balig).

2. Yang paling baik, seorang ibu hendaknya membimbing dan mengajari putrinya perilah masalah seks karena ia akan lebih yakin dengan penjelasan dan keterangan objektif ibunya tentang persoalan tersebut. Jika ibunya tidak ada, perannya bisa digantikan oleh pembimbing wanita lainnya seperti bibi. ${ }^{35}$

Salah satu tanggung jawab yang diberikan Islam kepada pendidik adalah menghindari anak (remaja) dari hal yang merangsang seks dan merusak akhlaknya. Hal ini dilaksanakan ketika anak mencapai usia puber dari umur 10 tahun hingga balig. ${ }^{36}$ Guna mewujudkan hal tersebut, pendidik memiliki tanggung jawab pengawasan terhadap remaja dalam hal-hal berikut,

1. Remaja masuk ke rumah (ruang) tanpa izin.

\footnotetext{
${ }^{32}$ M. Roqib, "Pendidikan Seks pada Anak Usia Dini", Insania; Jurnal Pemikiran Alternatif Pendidikan, P3M STAIN Purwokerto, Vol. 13 Nomor 2 Mei-Ags 2008, http://ejournal.iainpurwokerto.ac.id/index.php/insania/article/view/298, 9 April 2016.

${ }^{33}$ Marzuki Umar Sa'abah, Perilaku Seks Menyimpang..., hlm. 243.

${ }^{34}$ Ali Akbar, Seksualitas Ditinjau..., hlm. 40.

${ }^{35}$ Abdullah Nashih Ulwan dan Hassan Hathout, Pendidikan Anak Menurut Islam: Pendidikan Seks terj. Khalilullah Ahmas Masjkur Hakim dan Jalaluddin Rakhmat (Bandung: Remaja Rosdakarya, 1992), hlm. 119.

${ }^{36}$ Ibid., hlm. 33.
} 
2. Anak pada usia puber awal ( 9 tahun ke atas) bergaul dengan perempuan bukan muhrim.

3. Anak pada usia 10 tahun ke atas tidur dalam satu tempat bersama saudarasaudaranya yang laki-laki atau perempuan.

4. Menatap aurat perempuan terbuka sejak anak berusia mumayiz dan seterusnya.

5. Memberikan peluang kepada anak untuk menyaksikan film yang merangsang, drama erotis dan iklan-iklan jorok.

6. Membiarkan anak membiasakan kehendak nafsunya melihat gambar porno, majalah jorok, membaca kisah cinta yang merangsang dan mendengar lagu yang menyentuh naluri seksual tanpa pengawasan yang ketat.

7. Memberikan kesempatan kepada anak sejak usia puber dalam bergaul dengan perempuan teman dekatnya atau gadis tetangganya dengan alasan belajar. ${ }^{37}$

Hal-hal di atas harus diperhatikan secara seksama. Keluarga sebagai institusi pendidikan informal memegang peranan penting dalam menanamkan pendidikan seks yang benar yaitu melalui keteladanan, pembentukan opini (informasi yang benar), pengaruh lingkungan keluarga, menanamkan akidah dan akhlak yang baik sejak dini. ${ }^{38}$ Dimana tugas utama keluarga adalah menanamkan nilai-nilai hidup yang mendasar, seperti spiritual, religius, dan moral. ${ }^{39}$ Seperti yang ditunjukkan pada hasil riset yang dikemukakan Zelnik dan Kim dalam Avin Fadilla Helmi dan Ira Paramastri menunjukkan bahwa orang tua (keluarga) yang bersedia mendiskusikan seks dengan anaknya maka anaknya akan cenderung menunda perilaku seksual premarital. ${ }^{40}$

Pendidikan seks dengan demikian tak hanya menjadi tanggung jawab keluarga (informal), namun juga masyarakat (non formal) dan lembaga pendidikan (formal). Ketiga lembaga atau institusi pendidikan ini memiliki tanggung jawab yang bersifat sinergis guna memberikan pendidikan seks yang sehat dan positif sesuai perkembangan remaja itu sendiri. Islam sendiri menekankan pernikahan sebagai satusatunya jalan untuk menghalalkan hubungan seksual lelaki-perempuan.

\footnotetext{
${ }^{37}$ Lihat ibid., hlm. 36-41.

${ }^{38}$ Lihat Fuad Kauma, Sensasi Remaja di Masa Puber, (Jakarta: Kalam Mulia, 2003), hlm. 23-27.

${ }^{39}$ Abdullah Hasyim, dkk., Tanya Jawab Kesehatan Reproduksi dalam Pandangan Agama Islam, (Jakarta: Direktorat Advokasi dan KIE BKKBN, 2011), hlm. 77.

${ }^{40}$ Avin Fadilla Helmi dan Ira Paramastri, "Efektivitas Pendidikan Seksual Dini Dalam Meningkatkan Pengetahuan Perilaku Seksual Sehat”, Jurnal Psikologi, Fakultas Psikologi Universitas Gadjah Mada., Volume 25 Nomor 2 1998, http://jurnal.ugm.ac.id/jpsi/article/view/7502, 8 April 2016. 
Konsekuensinya adalah jika hubungan seksual dilakukan di luar pernikahan, maka hal tersebut terlarang dan berdosa besar. ${ }^{41}$

Sebagai bagian dari ajaran Islam, pendidikan seks memiliki signifikansi dan urgensi bagi remaja agar tidak mengalami hambatan dalam menjalani hidup pada fase pubertas. Urgensi pendidikan seks itu sendiri sebenarnya bersifat edukatif dan antisipatif. Oleh karena itu, pendidikan seks harus diajarkan kepada anak-anak (remaja) dengan cara yang setaraf dengan usia pertumbuhan mereka, baik di rumah maupun di sekolah. Pendidikan ini harus dilaksanakan dalam keseluruhan konteks ideologi Islam dan ajaran Islam agar para remaja, di samping memperoleh pengetahuan fisiologis dengan baik, memiliki kesadaran penuh terhadap kesucian hubungan seks dalam Islam dan dosa besar apabila menodai kesucian ini baik dari sudut Islam ataupun dalam pandangan Allah. ${ }^{42}$ Pendidikan seks perlu diberikan dan disampaikan kepada remaja guna menghindari berbagai bentuk penyimpangan seksual (seks bebas) yang berbahaya bagi kehidupan pribadi dan sosial remaja.

Ada berbagai macam perilaku seks bebas ${ }^{43}$ yang dianggap menyimpang baik secara agama maupun kultur masyarakat Indonesia yaitu seks pranikah, kumpul kebo, ${ }^{44}$ pelacuran, ${ }^{45}$ gigolo, ${ }^{46}$ homoseksual (gay dan lesbian) ${ }^{47}$ dan perkosaan. ${ }^{48}$ nSelain sebagai langkah prenventif dan antisipatif, pendidikan seks bagi remaja juga memiliki urgensi sebagai,

1. Sarana edukasi bagi remaja dalam memasuki jenjang usia remaja menuju dewasa (masa transisi).

\footnotetext{
${ }^{41}$ Fathurrofiq, Sexual Quotient, (Bandung: REMAJA ROSADAKARYA, 2014), hlm. 117.
}

${ }^{42}$ Abdullah Nashih Ulwan dan Hassan Hathout, Pendidikan Anak..., hlm. 149.

${ }^{43}$ Lihat Bgd. Armaidi Tanjung, Free Sex No! Nikah Yes! (Jakarta: Amzah, 2007), hlm. 3-46.

${ }^{44}$ Kumpul kebo adalah hubungan seks yang dilakukan berulang-ulang oleh seorang laki-laki dan perempuan sebagaimana layaknya pasangan suami isteri, namun tidak diikat oleh akad nikah dalam sebuah pernikahan. Pasangan kumpul kebo hidup serumah. Perbuatan ini melakukan hubungan seks seperti kerbau (kebo) tanpa ada ikatan melalui pernikahan yang sah. Lihat ibid., hlm. 7-8.

${ }^{45}$ Pelacuran adalah perbuatan hubungan seks bebas di luar pernikahan yang sah antara laki-laki dan perempuan dengan motif pemuasan nafsu seks yang salah satu pihak memberikan imbalan jasa pada pihak lainnya. Lihat ibid., hlm. 13-14.

${ }^{46}$ Gigolo adalah kebalikan dari pelacuran. Pelacuran merujuk pada laki-laki yang butuh nafsu seksnya dipuaskan oleh perempuan. Sementara gigolo merujuk pada wanita yang ingin nafsu seksnya dipuaskan oleh laki-laki, dengan memberikan imbalan pada laki-laki yang diinginkannya. Lihat ibid., hlm. 26-27.

${ }^{47}$ Perbuatan homoseksual (homosexual acts) atau perilaku homoseksual (homosexual behavior) mengacu pada kegiatan atau perilaku seksual antara dua orang yang berjenis kelamin sama. Jika dilakukan oleh sesama laki-laki disebut sebagai gay, sedangkan jika dilakukan sesama perempuan disebut lesbian. Lihat ibid., hlm.28-36.

${ }^{48}$ Perkosaan merupakan perbuatan seks bebas di luar pernikahan yang merugikan pihak lain yang diperkosa yakni perempuan. Perkosaan dilakukan dengan kekerasan karena dilakukan bukan atas dasar suka sama suka. Lihat ibid., hlm. 36-37. 
2. Memberikan panduan terkait seksualitas dan implikasinya.

3. Mengarahkan remaja kepada perilaku hidup sehat dan menghindari perilaku tidak sehat terutama yang berkaitan dengan masalah seksual.

4. Menghindari remaja dari perilaku penyimpangan dan kekerasan seksual.

\section{E. Kesimpulan}

Islam telah memberikan pandangan tentang pendidikan seks bagi remaja. Pendidikan seks memiliki urgensi bagi perkembangan diri remaja (muslim) dalam mengarungi kehidupannya yang kompleks. Pendidikan seks menurut Islam mengacu pada ajaran Islam yang bersumber dari al-Quran dan sunnah nabi serta sumber ilmiah kesehatan.Orang tua sebagai pendidik dalam keluarga memiliki tanggung jawab dalam mengarahkan dan membimbing anak-anak dan remaja kepada kehidupan yang berlandaskan pada nilai keislaman dan kemasyarakatan. Pendidikan seks bagi remaja yang efektif adalah dalam bingkai pendidikan keluarga.

Berbagai prinsip, tujuan, kurikulum dan urgensi pendidikan seks bagi remaja meniscayakan implementasi yang mampu membimbing remaja pada tahap kedewasaan dan kemandirian hidup. Tanggung jawab pendidikan seks tak hanya pada orang tua namun juga menjadi tanggung jawab guru/dosen, pemuka masyarakat dan tokoh agama serta pemerintah. Remaja adalah harapan bangsa di masa mendatang.

\section{Daftar Pustaka}

Akbar, Ali, Seksualitas Ditinjau dari Hukum Islam. Jakarta: Ghalia Indonesia, 1983.

Basyir, Ahmad Azhar, Ajaran Islam tentang Pendidikan Seks, Hidup Berumah Tangga, Pendidikan Anak. Bandung: Al-Ma'arif, 1996.

Desmita, Psikologi Perkembangan. Bandung: Remaja Rosdarkarya, 2008.

Fathurrofiq, Sexual Quotient. Bandung: Remaja Rosadakarya, 2014.

Fuad Kauma, Sensasi Remaja di Masa Puber. Jakarta: Kalam Mulia, 2003.

Halstead, J. Mark dan Michael Reiss, Sex Education Nilai dalam Pendidikan Seks Bagi Remaja; Dari Prinsip ke Praktek, terj. Kuni Khairun Nisak, Yogyakarta: Alenia Press, 2004.

LAL, Anshori, Pendidikan Islam Transformatif. Jakarta: Referensi, 2012.

Masland, Robert P. dan David Estridge, Apa yang Ingin Diketahui Remaja tentang Seks, terj. Mira T. Windy, Jakarta: PT. Bumi Aksara, 2000.

Mubin dan Ani Cahyadi, Psikologi Perkembangan. Ciputat: Quantum Teaching, 2006.

Muchtar, Heri Jauhari, Fikih Pendidikan. Bandung: Remaja Rosdakarya, 2008.

Mujiburrahman, Bercermin ke Barat: Pendidikan Islam Antara Ajaran dan Kenyataan. Banjarmasin: Jendela, 2013.

Mujtabah, Saifuddin dan M. Yusuf Ridwan, Nikmatnya Seks Islami. Yogyakarta: Penerbit Pustaka Marwa, 2010. 
Rahbar, Faramarz bin Muhammad, Selamatkan Putra-Putrimu dari Lingkungan Tidak Islami, terj. Kamdani, Yogyakarta: Mitra Pustaka, 1999.

Sa'abah, Marzuki Umar, Perilaku Seks Menyimpang dan Seksualitas Kontemporer Umat Islam. Yogyakarta: UII Press, 2001.

Tanjung, Bgd. Armaidi, Free Sex No! Nikah Yes!. Jakarta: Amzah, 2007.

Thalib, Muhamad, Bimbingan Kemesraan dan Seksualitas Islami. Yogyakarta: Pro-U Media, 2008.

Thawiil ath-, Utsman, Ajaran Islam tentang Fenomena Seksual, terj. Saefuddin Zuhri, Jakarta: PT. RajaGrafindo Persada, 1997.

Ulwan, Abdullah Nashih dan Hassan Hathout, Pendidikan Anak Menurut Islam: Pendidikan Seks, terj. Khalilullah Ahmas Masjkur Hakim dan Jalaluddin Rakhmat, Bandung: Remaja Rosdakarya, 1992.

Ulwan, Abdullah Nashih, Tarbiyatu 'l-Aulad fi 'i-Islam, terj. Saifullah Kamalie dan Hery Noer Aly, Semarang: Asy-Syifa', 1993.

Helmi, Alvin Fadilla dan Ira paramastri, "Efektivitas Pendidikan Seksual Dini dalam Meningkatkan Pengetahuan Perilaku Seksual Sehat", Jurnal Psikologi, Fakultas Psikologi Universitas Gadjah Mada., Volume 25 Nomor 2 1998,

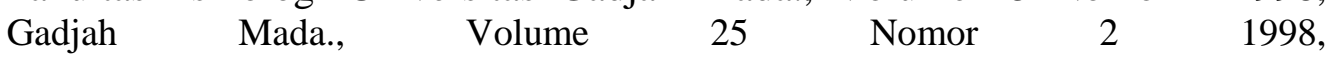
http://jurnal.ugm.ac.id/jpsi/article/view/7502, 8 April 2016.

Roqib, M., "Pendidikan Seks pada Anak Usia Dini”, Insania; Jurnal Pemikiran Alternatif Pendidikan, P3M STAIN Purwokerto., Volume 13 Nomor 2 MeiAgs 2008, http://ejournal.iainpurwokerto.ac.id/index.php/insania/article/view/298, 9 April 2016 